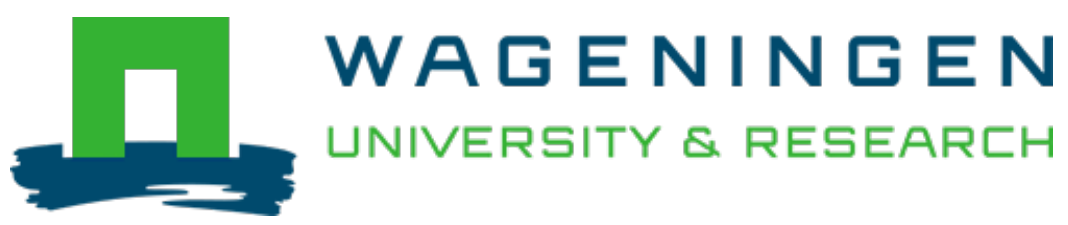

\title{
Making deforestation risk visible. Discourses on bovine leather supply chain in Brazil
}

\author{
Geoforum \\ Mammadova, Aynur; Behagel, J.H.; Masiero, Mauro \\ https://doi.org/10.1016/j.geoforum.2020.03.008
}

This article is made publicly available in the institutional repository of Wageningen University and Research, under the terms of article $25 \mathrm{fa}$ of the Dutch Copyright Act, also known as the Amendment Taverne. This has been done with explicit consent by the author.

Article 25 fa states that the author of a short scientific work funded either wholly or partially by Dutch public funds is entitled to make that work publicly available for no consideration following a reasonable period of time after the work was first published, provided that clear reference is made to the source of the first publication of the work.

This publication is distributed under The Association of Universities in the Netherlands (VSNU) 'Article $25 \mathrm{fa}$ implementation' project. In this project research outputs of researchers employed by Dutch Universities that comply with the legal requirements of Article $25 \mathrm{fa}$ of the Dutch Copyright Act are distributed online and free of cost or other barriers in institutional repositories. Research outputs are distributed six months after their first online publication in the original published version and with proper attribution to the source of the original publication.

You are permitted to download and use the publication for personal purposes. All rights remain with the author(s) and / or copyright owner(s) of this work. Any use of the publication or parts of it other than authorised under article $25 \mathrm{fa}$ of the Dutch Copyright act is prohibited. Wageningen University \& Research and the author(s) of this publication shall not be held responsible or liable for any damages resulting from your (re)use of this publication.

For questions regarding the public availability of this article please contact openscience.library@wur.nl 


\title{
Making deforestation risk visible. Discourses on bovine leather supply chain in Brazil
}

\author{
Aynur Mammadova $^{\mathrm{a}, *}$, Jelle Behagel ${ }^{\mathrm{b}}$, Mauro Masiero ${ }^{\mathrm{c}}$ \\ ${ }^{\text {a } T E S A F ~ D e p a r t m e n t, ~ U n i v e r s i t y ~ o f ~ P a d o v a, ~ V i a l e ~ d e l l ' U n i v e r s i t a ̀, ~ 16, ~} 35020$ Legnaro (PD), Italy \\ ${ }^{\mathrm{b}}$ Forest and Nature Policy Group, Wageningen University and Research, the Netherlands \\ ${ }^{\text {c } T E S A F ~ D e p a r t m e n t, ~ U n i v e r s i t y ~ o f ~ P a d o v a, ~ I t a l y ~}$
}

\section{A R T I C L E I N F O}

\section{Keywords:}

Fairness

Legitimacy

Transparency

Forest-risk commodity

Livelihoods

Zero deforestation

\begin{abstract}
A B S T R A C T
Large-scale agricultural production and trade of commodities is linked to deforestation risk in the tropics. This article explores political discourses of deforestation risk in the bovine leather supply chain in Brazil. It discusses how specific interpretations and practices of transparency in the leather supply chain affect legitimacy, fairness and sustainability outcomes. The article applies a political discourse analysis to data collected in multiple localities in Brazil between May and July 2018. The data entails thirty-nine semi-structured, recorded, and transcribed interviews, in the form of both face-to-face and video call interviews. We find that the concept of sustainable supply chains is as much a political term, as it is an economic and managerial term. The results show that different discourses articulate deforestation risk of bovine leather differently and highlights how the storylines of each discourse bring attention both to what is made visible and invisible in relation to sustainability, legitimacy, and fairness. Moreover, the results emphasise the importance of the role and voice of frontier settlers, by presenting how their storylines inform a political discourse on livelihoods. We argue that a simplistic understanding of transparency may lead to negative implications for livelihoods and sustainability outcomes. Accordingly, there is a need for increased public scrutiny of supply chains, including the leather one, and for special attention to unequal power relations and the importance of meaningful inclusion of vulnerable groups and populations.
\end{abstract}

\section{Introduction}

Large-scale industrial agricultural production and commodity trade are increasingly linked to deforestation and forest degradation in the tropics (Gibbs et al., 2010; Henders et al., 2015; Curtis et al., 2018). This is described via the concept of 'deforestation risk'. Agricultural products whose production or extraction involves deforestation and native vegetation clearing are classified as forest-risk commodities. Beef, soybeans, palm oil, and timber are considered the "big four" of forest-risk commodities (Walker et al., 2013; Pendrill et al., 2019). In debates on corporate social responsibility (CSR) and sustainable resource governance, deforestation risk is added to concerns over human rights violations, health and sanitation issues that need to be addressed by supply chain interventions (Walker et al., 2013). Specifically, sustainable supply chain management is a response of commodity markets to societal pressure by non-governmental organizations (NGOs) and civil society to reduce socio-environmental impacts of business operations (Gereffi et al., 2005). Accordingly, deforestation risk may be addressed via sustainable supply chain management.

Sustainable supply chain management focuses on transparency and traceability of company operations, responsible suppliers, and associated socio-environmental impacts. Over the last decades, transparency has evolved as a key element of environmental governance (Fung et al., 2007; Mol, 2010). Recent studies argue that for supply chains to be transparent requires mechanisms that incorporate both traceability of commodities across the chain and sustainability conditions of traders and suppliers (Egels-Zandén et al., 2015; Gardner et al., 2018). This is assumed to lead to positive governance outcomes: by reducing negative social and environmental impacts (Mol, 2010; Fung, 2013); by enhancing public accountability of businesses to civil society and consumers (Mol, 2015; Koberg and Longoni, 2018); and by balancing power asymmetries amongst stakeholders in the supply chain and promoting fairness (Mol, 2010; Gardner et al., 2018). Respectively, transparency is associated with positive outcomes in terms of sustainability, legitimacy, and fairness.

Transparency does not always lead to the desired positive outcomes

\footnotetext{
* Corresponding author.

E-mail addresses: aynur.mammadova@phd.unipd.it (A. Mammadova), jelle.behagel@wur.nl (J. Behagel), mauro.masiero@unipd.it (M. Masiero).
} 
and may lead to reverse impacts (Mol, 2010; Garrett et al., 2016; Gardner et al., 2018; van der Ven et al., 2018). First, supply chain information is often limited to business-to-business (B2B) relations, while actors in the beginning and end of the supply chain are neglected. Thus, there is a lack of evidence that consumers can leverage complex supply chain transparency information and assert their power through informed decision-making and preferences (Egels-Zandén and Hansson, 2016; Grunert et al., 2014; Janßen and Langen, 2017). Second, supply chain transparency information is usually made public in a complex, abstract and vague manner. This can obscure the ability and willingness of individual users to interpret given information accurately and act accordingly (Dingwerth and Eichinger, 2010). Third, transparency may result in reverse impacts as information is often produced and controlled by already powerful actors that may use this information to strengthen their position in the supply chain, for example with regard to price bargaining. This adds vulnerability to already vulnerable actors in the chain (Mol, 2010).

In addition to the big four forest-risk commodities (beef, palm oil, soy and timber), deforestation risk affects other commodities such as leather. In this article, we focus specifically on bovine leather from Brazil. The leather supply chain illustrates the complexity of supply chain transparency and the challenge to reach small suppliers and consumers at both ends of the chain. While the role of cattle in deforestation is subject to increased public scrutiny (Nepstad et al., 2006; Godar et al., 2012; Gibbs et al., 2016), the leather commodity chain has remained less visible until recently. We therefore explore how specific practices of transparency in the leather supply chain are linked to specific interpretations of sustainability, legitimacy, and fairness in governance outcomes. The results show how political discourses on deforestation risk and transparency affect decisions over what is made visible in the supply chain and how sustainability, legitimacy, and fairness are actually achieved or not. We conclude the article with a call for increased public scrutiny of commodity supply chains, including leather, and give special attention to the importance of meaningful inclusion of vulnerable groups and populations.

\section{Transparency and sustainable supply chains}

In the current age of globalisation, hierarchical mechanisms of accountability within governments are increasingly supplemented and replaced by horizontal modes of peer and public accountability, where civil society and the public holds powerful actors accountable for their actions (Bevir, 2010; Bäckstrand, 2008). At the same time, the complexity of globalisation and the lack of institutionalised relations makes it difficult to define the scope and boundaries of supply chains, in particular the actors that should be involved and held accountable (Gupta and Mason, 2016; Widerberg and Pattberg, 2017). In practice, accountability mechanisms thus often fail to hold powerful actors responsible or amount to little more than 'greenwashing' of consumer goods. Subsequently, supply chains of globally traded commodities invite political contestations about how transparency comes about and who should have access to information.

Political contestations about sustainable supply chains are often centred on ambiguities of meaning. That is to say that different political discourses will all lay claim to generally phrased positive outcomes such as sustainability, legitimacy, and fairness, but will define these terms in practice rather differently to fit their individual storylines. For example, while the concept of sustainability is intended to build bridges between the dimensions of economic development, nature conservation, and social inclusion, political discourse and social-ecological context often emphasize one dimension at the cost of the other two (cf. Higgins and Richards, 2019, Salas-Zapata and Ortiz-Munoz, 2018). Different dimensions of legitimacy may also be emphasized. As the supply chain spreads across geographies, the legitimacy of its activities can be supported by competing discourses highlighting economic, environmental or governmental justifications for corporate behaviour
(Behagel and Arts, 2014). Questions over fairness and responsibility also may have varying answers, as consensus over what is a fair distribution of responsibility across the chain is hard to find (Mair et al., 2017). Each type of outcome associated with transparency - sustainability, legitimacy, and fairness - is explored in detail below.

\subsection{Transparency and sustainability}

The causal relation between transparency and economic, environmental or social performance is still very difficult to estimate (Auld and Gulbrandsen, 2010; Ponte and Gibbon, 2011; Gardner et al., 2018) and contingent on where and what kind of undesirable behaviour is being scrutinized. Due to increased media and civil society attention, as well as limitations of data and resources, certain aspects of production systems can receive more attention than others. For example, coffee certification may place more attention on fairness of plantation workers than on avoided deforestation. Thus, transparency of one aspect can divert attention from, simplify or diminish the importance of others (Flyverbom, 2016; Gardner et al., 2018; Mol and Oosterveer, 2015). In other words, transparency tools target only the behaviour for which they are designed for.

For supply chains, the extent to which transparency leads to sustainability outcomes is particularly contested in cases of leakage, scope, and level of traceability (Mason, 2008; Mol, 2010). In the case of leakage, civil society pressure to abandon unsustainable practices may for example lead buyers to change suppliers but not to address the core problem. This creates the so-called effect of leakage of unsustainable operations to be carried on somewhere else (Henders and Ostwald, 2014; Garrett et al., 2016; Gibbs et al., 2016; Alix-Garcia and Gibbs, 2017). Second, by being concerned about sustainability of individual commodities, supply chain transparency may remain limited in scope: unless it is coupled with other governmental and civil society strategies, reduced impact of the supply chain of one commodity (e.g. sugarcane) may be cancelled out by increased impact of another (e.g. palm oil) (Larsen et al., 2008; Newton et al., 2013; Boström et al., 2015). Third, individual supply chain sustainability initiatives are always under the risk of contamination through laundry and introduction of unsustainable products into the system (Gibbs et al., 2016). For example, unsustainably produced products may be mixed with sustainably produced ones, i.e. animals may be moved across farms.

\subsection{Transparency and legitimacy}

Three important dimensions of legitimacy are legality, justification, and consent (Behagel and Turnhout, 2011; Schouten and Glasbergen, 2011, Beetham, 1991). The dimension of legality addresses the adherence of practices by actors with relevant legal norms and rules, in regional, national, and international jurisdictional contexts. This dimension presupposes an ordered system of operating as a valid basis for legitimacy. The dimension of justification is related to societal norms about what is considered good and just. Such norms can be external or internal (Beetham, 1991; Parkinson, 2003). For example, norms external to the supply chain may come from beliefs about the value of nature (e.g. providing ecosystem services) or from wider discourses about global sustainability, while internal norms may relate to how farmers view their relationship with a buyer of cattle. The dimension of consent relates to the social processes by which agreement to a practice or decision is given. For example, acquiring free, prior, and informed consent (FPIC) of local communities to carry out forestry operations is an increasingly recognised way to address social equity in global governance contexts (Mahanty and McDermott, 2013).

Transparency is relevant to each of the three dimensions of legitimacy. Adherence to legal norms and rules is often accompanied by governmental and private certification practices that aim to create public information about the performance of private actors in the supply chain. Questions over who is required to adhere to legal norms 
and rules or who should adopt private certification schemes therefore affect what type of legitimacy is produced. There also exists a big difference whether practices across the supply chain are evaluated according to norms external to the supply chain or internal to it. For example, whether economic development or nature conservation are more important grounds for legitimacy depends greatly on values and these will be weighed differently by an environmental NGO than by a meatpacker. Finally, which actors have access to information and how they can use that information to give or withhold consent for certain activities also affects legitimacy. A consumer who does not know where his/her burger is produced is not able to withhold consent for deforestation.

\subsection{Transparency and fairness}

Within the context of global commodity production and forest conservation, fairness is understood in multiple ways (Howard et al., 2016). First, fairness may relate to distributive justice regarding the distribution of benefits. This includes that local farmers are being paid a "living wage" regardless of market fluctuations. Transparency can have an adverse effect on this objective, when the sustainability of production is associated more strongly to the commodity than the conditions and location of its production. Second, it relates to structural equality and equity. Local suppliers are usually small or family farmers who lack the economic and political power to address structural and systematic causes of unsustainability. "Name \& shame" campaigns about impacts of commodity production often negatively affect the livelihoods of these already vulnerable communities (Gardner et al., 2018). Thus, economically vulnerable actors may carry the burden of transparency due to an absence of visibility of all actors of the supply chain (Schneider et al., 2015; Weber and Partzsch, 2018; Jakku et al., 2019).

Other dimensions of fairness relate to procedures and institutions. Access to land titles, bureaucracy, and transaction costs all have big impacts on the livelihoods of local actors, often much more so than on the sales of individual companies sourcing from the region. Making previously invisible actors and impacts more visible may therefore once again add to the vulnerability of these actors and to their ability to enter markets without proper titles. Thus, when transparency is used to increase surveillance (Gardner et al., 2018), it can also push the responsibility and associated cost of compliance to those upstream actors at the beginning of the supply chain that lack substantial resources to either adhere to the standards or to demonstrate sustainable behaviour already in place (Gupta, 2010; Gebara and Agrawal, 2017). It is often much easier for companies in the middle of the supply chain to disassociate themselves from illegal and unsustainable activities than it is for smallholders at the beginning of the supply chain. This power imbalance impacts fair benefit sharing as well, as price margins are usually higher towards the end of the supply chain.

In international climate change debates, fairness is linked to the principle of equality and non-discrimination. The developed countries that demand tropical forest states to conserve their forests, might be "free-riding" by previously having had a chance to exploit their resources for economic development (Armstrong, 2016; Page, 2016). At the same time, the negative publicity of the production by tropical forest countries can lead to trade barriers and is therefore against the "non-discrimination" principle of the World Trade Organization. Other important principles in the international domain are intragenerational and intergenerational fairness. Although deforestation may be a necessary pre-condition for livelihoods of a settlement, its effect is felt in longer distances and by future generations. Thus, fairness in international trade amongst nations may compete with ideas of intergenerational fairness and the idea of the common good.

\section{Research approach}

\subsection{Discourse analysis}

In this article, we focus on different choices that can be made to include transparency concerns and instruments in the supply chain of leather as a forest-risk commodity. These choices are strongly structured by the societal discourses that actors in the supply chain adhere to, i.e. how they publicly discuss broad topics such as economic development, environmental conservation, and the rule of law. Such discourses may be centred around the ideal of nature conservation, economic development, or another important social issue, as we illustrate in the results below. Specifically, we consider how these public debates steer choices for specific policy instruments, acceptance of responsibility, and valuation of deforestation risk. Moreover, we analyse how these discourses emphasize different dimensions of sustainability, legitimacy, and fairness. This kind of systematic and comparative review of actors, coalitions and their discourses remains mostly absent in academic literature. This research aims to close that gap and seeks to provide a basis for comparative analysis with the discourses and narratives present in other countries and for other commodities.

The results are based on a discourse analysis (Hajer and Versteeg, 2005; Sharp and Richardson, 2001; Torfing, 2005) for the leather supply chain in Brazil. We understand discourse as "an ensemble of ideas, concepts and categories through which meaning is given to social and physical phenomena, and which is produced and reproduced through an identifiable set of practices" (Hajer and Versteeg, 2005, p175). Such ideas, concepts and theories, in the context of this article, refer specifically to ideas about sustainability objectives, dimensions of legitimacy, theories of fairness, and so on. These different elements of a discourse become connected and fixed in relation to each other in storylines. Accordingly, these storylines represent simplifications of reality that make the world manageable and possible (cf. Behagel and Turnhout, 2011). Specifically, the discursive idea that a commodity travels across a supply chain makes the sharing of responsibility for negative impacts across different actors possible. We identify discourses as they are reproduced by a discourse coalition, which is "... a group of actors that in the context of identifiable set of practices shares the usage of a particular set of storylines over a particular period of time" (Hajer et al., 2006, p70; Elgert, 2012). Thus, we use a discourse coalition approach to understand how certain storylines are (re)produced and transformed by actor coalitions within the context of the leather supply chain in Brazil.

\subsection{Data collection and analysis methods}

The data collection is focused on how Brazilian bovine leather is given meaning as a forest-risk commodity. It includes the review of publications, grey literature and qualitative data collected during an extended field work visit of the first author in the Brazilian states of São Paulo, Para, Mato Grosso, Mato Grosso do Sul, and Rio Grande do Sul in May-July 2018. The data collection was conducted before the change in federal government in Brazil in 2018 and the presented results reflect the context of pre-election period. Despite some changes in the official rhetoric and strategies of the new government, we do consider the identified discourses still relevant and enduring till today. The collected qualitative data entail thirty-nine semi-structured, recorded, and transcribed interviews, in the form of face-to-face (thirty-one) and videocall (eight) interviews. Additionally, field notes, observations and notes based on unstructured interviews during visits to meatpacking plants, tanneries, farms, fairs and workshops were included in the analysis. Grey literature and online publications were used to enrich the analysis and to better understand the storylines supported by each discourse coalition. The criteria for choosing these publications were based on both a) snowball sampling - i.e. publications actively suggested by interviewees; and b) an active online search based on keywords distilled from the interviews and observations. 
Interviewee selection was based on a broad set of criteria - including prominence of interviewees in key events, formalized networks, decision-making authority, impact of statements on the public discourse, and authorship of key documents. Additionally, snowball sampling was used. Given the vast territory of Brazil, as well as the diversity and extensive number of stakeholders involved, we aimed to use a nonprobability sampling approach that allow covering those with important information power (Malterud et al., 2016).

Data analysis consisted of qualitative coding of the material in several rounds using the research software Atlas.ti 8. First, the transcribed material was reviewed and coded based on empirically emerging themes and concepts to identify major storylines and discourse coalitions. A second round of coding was applied based on the theoretical concepts and categories discussed in the first section of this paper. Here, articulations of transparency, sustainability, legitimacy and fairness in different storylines of diverse discourse coalitions were identified. All interviewees gave informed, prior and written consent to be recorded for the purpose of this research. The quotes from the interviews are kept anonymous to protect economically, socially, and/or politically vulnerable respondents. The results are presented below. A short background is first offered on the history of deforestation in the Brazilian Amazon. After that, the main part of the results discusses three discourse coalitions and their major storylines as represented in the data.

\section{Results}

\subsection{A short history of deforestation in the Brazilian Amazon}

"The history of Brazil is the history of land grabbing and occupation" ...

(Anonymous, Personal communication, June 7, 2018)

Deforestation associated with cattle ranching in the Brazilian Amazon has developed as a result of a historical trajectory of socioeconomic and political processes within the country. Large-scale economic exploitation of Amazonian forests started with the second rubber extraction cycle during the presidency of Getúlio Vargas (1930-1945), continued in the 1960s under the nationalist slogan "integrate not to deliver" (Integrar para não Entregar), in the 1970s under the slogan "Land without man to men without land" (Terra sem homem, para homem sem terra) and was supported by the construction of highways traversing the Amazon from north to south - Cuiabá-Santarém (BR-163) and from east to west - Transamazonica (BR-230). This mass migration gave rise to many unresolved social issues, including social injustice, land tenure conflicts, and violence against indigenous people and traditional communities.

The Amazon forests and the adjacent tropical savanna biome of Cerrado experienced another wave of exploitation and deforestation once Brazil started establishing its role as a major provider of agricultural commodities in the 1990s. Within the period of 1990-2003, cattle production within the Legal Amazon ${ }^{1}$ increased $240 \%$ and reached 64 million heads (IBGE, 2018). This contributed a to an annual 28 million ha of deforested land in 2004, the worst deforestation value in the history of the region (Fearnside, 2005; Kaimowitz et al., 2004; INPE, 2019). Thanks to a mix of public and private interventions, deforestation in Legal Amazon was reduced in the period of 2004-2015 to a 5-6 $\mathrm{K} \mathrm{km}^{2}$ average annual deforestation. Deforestation started to increase again to 7-8 $\mathrm{K} \mathrm{km}^{2}$ in 2016-2018 (Nepstad et al., 2014; Gibbs

\footnotetext{
${ }^{1}$ The administrative unit of Brazilian Legal Amazon was established by Federal Law No. 5.173 (Art. 2) and surrounds the states of Acre, Amapá, Amazonas, Pará, Rondônia, Roraima, Tocantins, Mato Grosso, and part of Maranhão. Covering more than $5 \mathrm{mln} \mathrm{km}^{2}$ (two thirds of Brazil), the Legal Amazon encompasses all the Amazon Biome, $37 \%$ of the Cerrado, and $40 \%$ of the Pantanal Biome (FAO, 2019).
}

et al., 2015, 2016; Moutinho et al., 2016; INPE/PRODES, 2019). It reached $9.7 \mathrm{~K} \mathrm{~km}^{2}$ in 2019 and the summer months of 2019 saw almost $200 \%$ increase in deforestation in some states compared to the same months of 2018 (INPE/PRODES, 2019). Due to low initial capital investment and consolidation of soy plantations in productive lands, cattle ranching has gradually become a major economic activity of the frontier settlements (Gardner, 2009; Pacheco, 2012). It has also become the most profitable way for demonstrating productivity on the land to seek land titles under usucapio or usucapt rules and to avoid confiscation for Agrarian reform (Law 8629 of 1993) once the title is obtained. Thus, in addition to a livelihood, cattle ranching has become an activity involved in land grabbing (grilagem) and land speculation (Bowman et al., 2012; Pereira et al., 2016).

Since the 1970s, international and national environmental NGOs have paid increasing attention to deforestation in the Amazon and played a crucial role in the establishment of protected areas, indigenous territories and extractive reserves for rubber tapping in the region. For privately owned lands, the Brazilian Forest Code of 2012 (Law 12,651/ 2012) constitutes an attempt of the federal government to limit deforestation. The Forest Code requires private landowners to keep a certain percentage of their properties in the form of Legal Reserve (LR) and Permanent Protection Areas (PPA) depending on the biome they are located in. If a property is located within the limits of Amazon forest biome, legal requirements include the conservation of $80 \%$ of the land area in native vegetation as LR. This percentage is $35 \%$ in the Cerrado (Brazilian savanna), and 20\% in all other biomes. The Forest Code also established the system of Rural Environmental Registry (Cadastro Ambiental Rural, CAR), requiring all rural private properties to register in the national system and to provide the georeferenced coordinates of the boundaries and remaining forests within the property (Azevedo et al., 2015). While registration of private properties under the CAR is required by law, deadlines to do so have been extended multiple times, recently to December 31, 2019 (SICAR, 2019).

Over the last decade, forest conservation strategies in the Amazon have become focused on politicizing commodity supply chains and bringing visibility to the impact of international commodity markets (Barbosa, 2015). In 2007, the Brazilian Institute of Environment and Renewable Natural Resources (Instituto Brasileiro do Meio Ambiente e dos Recursos Naturais Renováveis, IBAMA) published the "priority list" largely known as "blacklist" - of municipalities with most deforestation. This led to intense government control, "naming \& shaming", and restriction of access to federal credit. In 2009, the Federal Public Prosecution Service (Ministério Público Federal, MPF) of the state of Pará and IBAMA sued ranchers and slaughterhouses that deforested illegally and threatened to sue big retailers and supermarket chains that bought from them. The big slaughterhouses signed Terms of Adjustment of Conduct (TAC) agreements with the MPF in July 2009 committing to avoid purchases from properties with illegal deforestation (Gibbs et al., 2016; Barreto et al., 2017). At the same time, Greenpeace published a report called "Slaughtering the Amazon", where major meat and leather producers were accused of driving deforestation. This has led the biggest four Brazilian slaughterhouses - JBS, Minerva, Marfrig and Bertin - to sign a private agreement with Greenpeace, largely known as G4 Agreement or Zero Deforestation Cattle Agreement. Under this agreement, the slaughterhouses agreed to put monitoring and auditing systems in place to avoid being involved with deforestation. Two subsequent operations called Carne Fraca (Weak Meat) and Carne Fria (Cold Meat) in 2017 revealed more illegality and corruption in the sector. In 2017, Greenpeace left the private agreement citing a lack of sincere efforts and robust measures by the slaughterhouses to act on deforestation risk (Greenpeace, 2017).

\subsection{Deforestation risk discourses in the leather supply chain}

Historical developments have produced strong public debate around issues such as: who is responsible for increasing environmental 
degradation and deforestation in the Amazon region; who should bear the costs for forest conservation; and what kind of measures are considered indiscriminate and fair. Within this context, different actor coalitions frame historical events in a distinct way and engage in a discursive production of reality through storylines and practices. Based on the collected data, we identified and named these discourse coalitions as 1) Order and Progress (Ordem e Progresso) 2) Livelihoods and 3) Zero deforestation. We present the coalitions and their discourses below.

\subsubsection{Order and progress}

The discourse of Order and Progress is found in the national motto of Brazil and in slogans such as Integrate not to deliver. This discourse is institutionalized in many policies and policy instruments. The coalition of its supporters consists of major government agencies, producer associations, roundtables, and the private sector in general. By representing a dominant discourse in public debates around development of the Amazon, it has historically developed to include the storylines of a) Brazil as a green producer, b) sustainability as legality, c) common but differentiated responsibilities (CBDR).

(a) The major storyline of this discourse is of Brazil as a green producer and exporter that feeds more than 1.5 billion people across the globe, as was found in our analysis of statements by the coalition supporting this storyline. The argument is that the world has hunger and Brazil feeds it. From being a net food importer in the 1970s, Brazil transformed itself into net food exporter today and has established itself as an important producer of agriculture products. The country aims to strengthen its position as a provider of agricultural products by planning on increasing the production to reach 13.7 million tons of beef by 2030 (GTPS, 2018).

The storyline of green production argues that Brazil should be applauded for managing to secure its position as an important producer and exporter of agriculture products while allocating $30 \%$ of its territory for conservation and indigenous territories. It also argues that Brazil invests a lot in solidifying agriculture lands and intensification of production. Intensive and technology-based agriculture is the future for Brazil and for the world.

With technology, engaged people and sustainability, Brazil sets the example in production and conservation, being a reference in the fight against hunger and showing the path to other nations (Ciasulli, 2019)

This storyline also emphasises that Brazil is a proud producer of bovine leather products and exports leather to around 80 countries in the world (CICB, 2018). High quality and socio-environmental standards is said to allow Brazilian leather to be used in fashion, upholstery and the automotive sector. The leather industry moreover embraces the philosophy of circular economy and argues that it turns the biological waste of the meat industry at the slaughterhouse into valuable items.

The Order and Progress discourse coalition often uses the story that unprecedented growth of Brazilian exports is thought to have scared its competitors. This is then connected to another story that holds that environmental organizations are sponsored by international funds to work against progress of the country.

...Sustainable development has three pillars, economic, social and environmental. Just the way the US has been recognized for its economic power and Norway for its successful social reforms, the example of Brazil in environmental sector should be recognized internationally. (Anonymous, Personal Communication, 08 June 2018)

(b) The second storyline of the Order and Progress discourse is that sustainability is equal to legality. It argues that the percentages established by the Forest Code of 2012, the CAR system and the forest monitoring systems developed by the government create reliability and transparency that allow effective governance. Accordingly, the storyline argues that NGOs' request to make public Animal Transport Guides (GTA) for tracking animal transport across farms is both unacceptable and unnecessary, as transparency over this kind of information can disrupt the market and compromise already achieved regulatory success.

The idea behind the storyline that sustainability equals legality is that Brazil has one of the most robust environmental legislations in the world. Sustainable production is the one that follow legal rules and regulations. Zero illegal deforestation by 2030 is the main target. Zero gross deforestation requirements ${ }^{2}$ put forward by the environmental NGOs are therefore considered an "unconstitutional and illegitimate NGO hoax" (Anonymous, Personal Communication, 27 June 2018) for demanding higher standards than those set by federal laws. It directly interferes with the sovereignty of the Brazilian government over its own territories. Brazil has already "lost" its territories to international forces when conservation areas and indigenous territories were created. Zero deforestation requirements are another way to make Brazil lose its control over Amazonian resources.

So, the reason why we didn't use just one criterion, let's say zero deforestation as a proxy to sustainability? Because we have a lot of modern legislation on conservation of natural vegetation inside the property. When we have been discussing indicators and forest conservation inside GTPS, the forest code was also under discussion. It was approved in 2012. This legislation allows certain \% of your property to be cleared legally. And not all areas in Brazil have been already cleared. If I have an area that I inherited from my family and if my grandfather used only 5\% of the area, then I have the right to use the other 15\% $m$ (Anonymous, May 11, 2018)

(c) The third storyline of Order and Progress discourse focuses on common but differentiated responsibilities. It argues that developed countries have exploited their rights to deforest and develop, while the same rights are being denied to Brazil. If Brazilian forests provides ecosystem services for the whole world, then the Brazilian government should be supported with conservation efforts and landowners need to be financially compensated for keeping forests intact within their private territories. It is also considered unjust to demand of farmers to give up their legal right to deforest. Payment for Ecosystem Services and other mechanisms are therefore needed compensate farms for the foregone profit per head of animal. This storyline also argues that consumer markets abroad should pay a premium for environmentally friendly products that Brazil is producing, including beef and leather.

In addition to its focus on financial compensation, the storyline argues that Brazil pays a high cost for being rich in biodiversity as a country. While Brazilian cattle production is mainly based on open pasture lands, Brazil is considered to face unjust discrimination in international trade. It is argued that nowhere in the world a rural farm is required to keep a forest reserve within their private properties and yet Brazilian farmers face a bad reputation linked to deforestation (Miranda, 2018). Thus, Brazil is said to carry double costs - the cost linked to preserving the forests even within rural properties, plus the cost of a negative international reputation that affects sales and premiums.

\subsubsection{Livelihoods}

Smallholder farms of settlements, best-practice farms (PECSA, São Marcelo, etc.) and solution-oriented NGOs (Amazon Environmental Research Institute (IPAM); The Nature Conservancy Brazil (TNC);

\footnotetext{
${ }^{2}$ In Brazil, the discussions around zero deforestation focuses on zero legal and illegal deforestation. The Forest Code of 2012 allows certain percentage of native vegetation clearing in private properties according to biome types. NDCs of Brazilian government support zero illegal deforestation by 2030 . When it comes to cattle, while public Terms of Adjustment of Conduct (TAC) between Public Prosecutor and major slaughterhouses in 2009 addresses zero illegal deforestation, private G4 agreements between Greenpeace and four main slaughterhouses in 2009 puts a commitment to stop zero legal deforestation as well in sourcing farms.
} 
Instituto Centro de Vida (ICV); Amigos da Terra - Amazônia Brasileira; National Wildlife Federation; IDH - Sustainable Trade Initiative; Earth Innovation Institute, WWF Brazil, etc.) are the coalition that support a discourse around socio-economic livelihoods. While they do not necessarily share deep social and environmental values, their interpretations of certain events and realities come together in storylines a) how socio-economic-factors cause deforestation, b) that land tenure is at the core of the deforestation issues, and c) that express a preference for finding local solutions.

(a) The central storyline of the discourse is that historical and structural socio-economic factors lead to deforestation. The storyline highlights the issue of fairness and historical injustice. It argues that settlers were promised to find economic opportunities in the middle of the forest and that they are cheated when faced with reality and hardships of everyday life. This is a central element of the collective memory in many settlements. Lack of proper settlement planning, shortage of public services such as schools and medical centres strengthen this storyline. While it was a government initiative and policy to occupy Amazon in the 1960s, settlers are now paying the cost of deforestation and are being scrutinized as criminals. The government repeatedly failed to deliver its promises, while putting pressure on farmers through command and control mechanisms that increased around 2009. That time is remembered by some as traumatic:

The Minister of Environment arrived by helicopter with armed forces and put that into $6 \mathrm{pm}$ news calling everyone in the area bandits. This is not something you want to see with your children. So, there has been a lot of resentment building up against the federal government. They confiscated millions of cows from the public land that should not be used. That was a big a shock for the area, where cattle mean money and livelihood (Anonymous, Personal Communication, May 28, 2018)

(b) The second storyline of the Livelihoods discourse frames land tenure as at the core of the deforestation. Obtaining land titles is a slow and bureaucratic process that incentivizes illegality. Insecure land rights incentivise actors to maximize their profit in a short time through exploitation of forests. Thus, supporters of this discourse argue that government should work efficiently in clearing up land disputes and allocating titles if the aim is to reduce deforestation and create legitimacy.

Associated with the land tenure issue is the argument that conservation of $80 \%$ is an extra burden upon a farmer due to costs of forest management plans, fighting forest fires, managing the attack of wild animals, and so on. The storyline holds that responsibility and cost of forest conservation is pushed upon private properties, a function that a government is responsible for in any other country. It moreover argues that if forest conservation is important for the government, then it needs to implement proper zoning and distribute lands only in the areas that are good for production. Allocating "undesignated" public lands to a certain category of protection or usage is considered key to stopping land grabbing and associated deforestation in public forests.

Insecurity of the tenure situation is compounded by the postponing of deadlines for the CAR registry, and regular changes and differences in percentages of allowed deforestation and cut-off dates. Supporters of the Livelihoods discourse argue that transparency and CAR registry requirements will not address leakage of deforestation to elsewhere as long as it is profitable to be illegal.

One of the things in the Forest code is that it defines what smallholders had in terms of native vegetation up to 2008 as their legal reserve. So, what signal do you give once again? You are a smallholder and I am a smallholder. I am a bad person and I had a plot of land of 100 ha and I opened 100 in 2000. We both moved in 2000 and you were too concerned about environment and you opened only $10 \mathrm{ha}$. And here comes the law of 2008 or 2012 and it says, I am ok. I can still have cattle, soy or whatever in my 100 ha and you can only open another $10 \%$ if you are in Amazon biome and if you have a license. So, what does it say today?
Being illegal is ok. (Anonymous, July 4, 2018).

(c) The third storyline of the discourse puts preference on finding local solutions through better farming practices, and fair benefit and cost sharing, as opposed to "naming \& shaming" techniques. In the past, when NGOs pressured slaughterhouses and retailers to act, the latter did not invest in farm sustainability and just sufficed with "blacklisting" and boycotting. These actions had local repercussions at a deeper level. It eroded trust in and weakened support for the environmentalist agenda of NGOs and the Brazilian government at the time. New zero legal deforestation requirements without compensation are therefore considered unfair and unsustainable. Compensation mechanisms are necessary to support farmers to intensify and adopt best practices and make them conserve forest reserves on their land. In other words, if $20 \%$ of the land is the limit, then consumers need to take responsibility and be ready to pay local farmers for it.

... and then comes Greenpeace and says: "You did deforestation, you are a criminal". So, they don't understand the historical process of the Amazon, and they criminalise our production. The day Greenpeace arrives here to see and understand the agrarian system and the distribution of land, and the difficulties we are going through, $60 \%$ to $80 \%$ of the problems can be solved (Anonymous, Personal Communication, 22 May 2018).

Another local issue that is debated is that slaughterhouses have the power to dictate the price of cattle and do not offer a premium for sustainability. The only premium that is offered is for the quality of meat. While farmers get paid per arroba ( 1 arroba $=15 \mathrm{~kg}$ ) of meat, they do not get compensated for animal skin for the leather industry. The profits gained by slaughterhouses and tanneries are not reaching the farmer, the real producer of the product. Meanwhile the farmers are required to maximize their profit within the limit of $20 \%$ allowed land, and to invest in traceability and intensification. If leather brands want sustainable and deforestation-free leather they must sit at the roundtable with producers, engage and make sure the payment for sustainable production reaches the farmers.

What they are doing today is push the responsibility of preservation only upwards on the producer...Nowadays, the Prada brand is valued more than the standing forest (Anonymous, Personal Communication, 23 May 2018)

\subsubsection{Zero deforestation}

Following the historical discourse of conservationists that biodiversity is the global "heritage of humankind" (UNESCO 1972) this discourse coalition, with prominent supporters such as Greenpeace, the federal Brazilian agency IMAZON, international scientific journals and ecologists, public prosecutors, and the Brazilian Institute of the Environment and Renewable Natural Resources (IBAMA), considers Amazon forests as the heritage of all humankind and its protection the duty of everyone. It includes the storylines of a) the possibility of a 'tipping point' of the Amazon biome, b) robust measures for forest protection, and c) the danger of reverse incentives.

(a) The first storyline is about the concern around a tipping point of Amazonian deforestation. Only 1\% of Amazon forests were deforested in 1970 and today that is $20 \%$. Scientists argue in journals such as Science and Nature that the continuous deforestation coupled with a feedback loop of climate change can exacerbate the situation to the point of no return and have catastrophic consequences for the whole planet (Lovejoy and Nobre, 2018). This involves a tipping point where the hydrological cycle of the rainforest would be broken, effectively turning the whole Amazon into a dry forest or a savanna type of biome. Thus, further deforestation is not sustainable, whether legal or illegal. Moreover, reforestation in already deforested areas and properties with environmental liabilities should start immediately. This also requires that consumers adjust their diets to exclude forest-risk commodities and 
hold the businesses that deforest accountable. The storyline also argues that supermarkets, leather brands and slaughterhouses carry direct responsibility and publicly pressuring these downstream actors is therefore an effective strategy.

(b) The second storyline of the Zero Deforestation discourse argues for robust and beyond-current-legality measures to protect the forests. The Forest Code and its provisions are not considered enough to protect the Amazon. Rather, legal measures for forest conservation in Brazil are considered the result of long-lasting political debates and lobbying by agricultural interest groups and therefore not the most effective and legitimate. Supporters of the discourse moreover argue that 58 of the 84 articles of the 2012-revised Forest Code (i.e. the current Forest Code) infringe on the Brazilian Constitution and should be withdrawn. These articles are considered to favour deforestation and remove environmental protections. For example, Article 12 (a) allows Amazonian states to reduce the legal reserve requirement for rural properties from $80 \%$ to $50 \%$ if conservation units and indigenous reservations make up more than $65 \%$ of their territory (Freitas et al., 2018).

The idea of "lets first deal with illegal deforestation and then find solutions for the legal one" is not supported as a robust measure. The extent to which legal deforestation is inherently sustainable is strongly questioned. Ever changing baseline cut-off dates, amnesties to forgive first pre-1998 and then pre-2008 deforestation and de-regularization of protected areas are argued to demonstrate significant flaws in the capacity of current laws and regulations to preserve the forests. The current Forest Code is moreover thought to be too lenient on landowners and influenced by the rhetoric of agrobusiness. That is the reason why in 2016 Greenpeace started the campaign for a "Zero deforestation law".

The Forest Code and CAR are thought inadequate to provide enough transparency over meat and leather supply chains. With current rates of registration, it will take decades for the Secretariat of Environment and Sustainability (Secretarias de Meio Ambiente e Sustentabilitade, SEMAS) to check and verify the forest reserve of the CAR registries. At the same time, there is still a great deal of illegality and informality happening in the sector. GTAs should therefore be made public to trace individual animals and be linked to the CAR registry to have a better and more reliable monitoring system and avoid leakage of deforestation risk. Slaughterhouses should start identifying and monitoring their indirect suppliers and producer associations in different states and help make GTAs transparent.

Robust measures mean that every actor in the cattle supply chain is thought to carry responsibility, including retailers/supermarkets and the leather tanneries and their customer brands. Pressuring these consumer-facing actors with reputational risk is the proven way to achieve some change in the sector since MPF prosecutions and the report of "Slaughtering the Amazon" and "Hora di Conta" in 2009. The leather sector cannot source illegal and deforestation risk leather. It needs to invest in traceability and send a clear signal to upstream producers: everybody needs to participate in this ethical call.

About $70 \%$ of the slaughter capacity is now owned by slaughterhouses that signed an agreement with the Public Prosecutor to stop buying from the areas that illegally deforest. So, we still have about 30\% of slaughter capacity that is owned by companies with no commitments. And this $70 \%$, although they have the commitments, they still deal with direct suppliers. So, we still have problems with control. Today we cannot say for sure that any cattle are deforestation-free. So, we cannot talk about deforestation free leather either. [..] It is very important that the market takes a position. It is more likely for ranchers to listen to the market than to public policy or NGOs. (Anonymous, Personal Communication, 24 May 2018).

(c) The third storyline of this discourse is framed around the danger of reverse incentives through compensation, premium prices and intensification of the production. It is the ethical duty of the farmers to produce sustainably and the responsibility of the supermarkets to make sure that all products are sustainable by default. Citizens and consumers are still exposed to deforestation and social crimes via the beef they find in the supermarket shelves. If slaughterhouses and supermarkets do not fully control their cattle supply chain, consumers have little power to avoid complicity in a problem that they cannot solve. A premium for sustainability is then a wrong incentive in the case of Brazilian beef.

I don't want to enter a supermarket and have a choice of paying extra for a meat without deforestation and illegality. What does it mean? That the rest of the meat products are illegal and with deforestation risk? (Anonymous, Personal Communication, 26 June 2018)

The argument against paying a premium for avoided deforestation is moreover that society and environment have paid enough historically for deforestation and illegality. Examples are historical and current violence against indigenous people and traditional communities as part of deforestation and land use change. The storyline thus expresses the idea that it is not fair to ask for compensation to stop doing illegal and unsustainable activities, it is a wrong incentive. It is also not fair that the taxpayers are paying for government projects to monitor the deforestation, rather than agribusiness for example. Brazilian society also pays indirectly by experiencing the economic crisis and the negative reputation of the Brazilian production abroad.

In this storyline around incentives, the commodity of beef or meat is identified as the worst environmental problem today and the number one contributor to climate change: it leads to deforestation, methane release, a large virtual water footprint and pollution of water systems through animal waste. Intensification can support the growing demand for meat up to certain extent, however at some point more land will be required. Instead of investing valuable resources into intensification we need to rethink our diets and change to plant-based products. By proxy, this also extends to the use of leather and adopting plant-based alternatives such a "fruitleather".

\section{Discussion}

The three discourses discussed above all include references to sustainability, legitimacy, and fairness, of which they highlight different dimensions. These political discourses therefore suggest multiple and diverse points of emphasis in which a leather supply chain should be organised (Fig. 1). This diversity creates a basis for what kind of transparency is considered important and what kind of sustainability, legitimacy, and fairness is desirable. For the transparency of the supply chain, this translates to different ideas about data collection and monitoring of different actors, production processes and trade within the chain (Flyverbom, 2016; Gardner et al., 2018).

An important general point of reflection that the results did not show very clearly is that discourse coalitions do not possess rigid boundaries and that coalition members might travel from one discourse to another across storylines, even though antagonistic relations between different discourses often prevent this from occurring. For example, although IPAM was included in the Livelihoods discourse coalition, their leading efforts and campaign for zero deforestation in Brazil is well recognized by many stakeholders (although their approach to achieve zero gross deforestation might differ from that of Greenpeace). Indeed, discourse analysis demonstrates that actors can be part of a discourse coalition without necessarily sharing deep values or core beliefs (Hajer et al., 2006). Regardless the strictness or flexibility of membership of discourse coalitions, the identification of three separate discourses does point towards competing claims to the purpose and governance outcomes in transparency mechanisms in the leather supply chain in Brazil.

\subsection{Sustainable, legitimate, and fair supply chains}

Our analysis of the various storylines of each of the three discourse brings attention both to what is made visible and invisible within each 


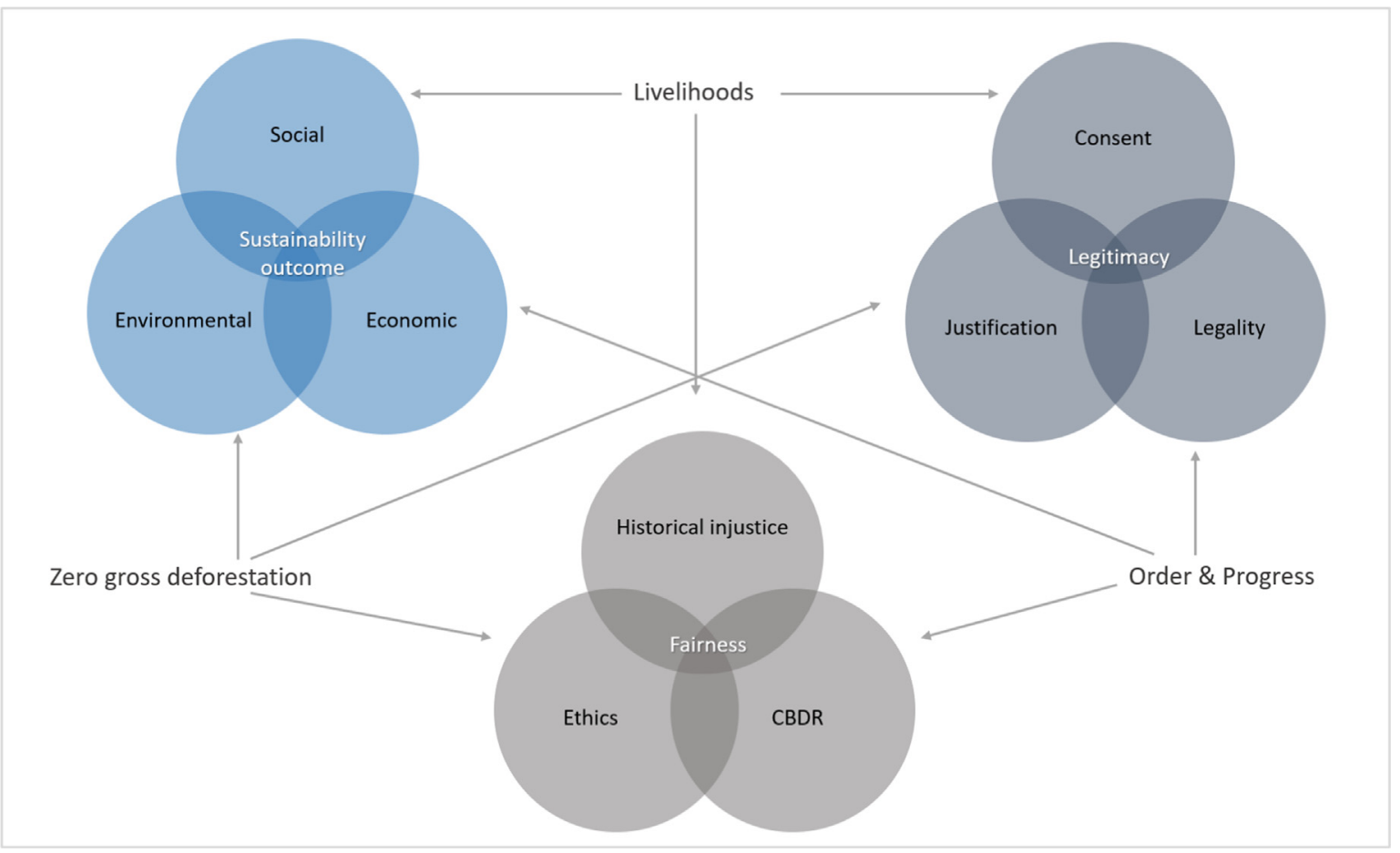

Fig. 1. Play of emphasis and visibility over different elements of sustainable supply chains by the identified discourses.

political discourse. For sustainability this play of visibility leads to different interpretations of the term (Newberry, 2014; Pirard et al., 2015; Higgins and Richards, 2019). While the Order and Progress discourse focuses on the need to recognize Brazil as an important producer of agriculture products, it also seeks recognition for the efforts made to achieve good environmental governance. By focusing on the "greater good" of feeding the hungry world, the discourse sheds light on the increasing demand for agriculture products worldwide, while issues such as inefficient food distribution and correlation between rise of middle class and demand for beef are overlooked. The definition of sustainability by the Livelihoods discourse puts much more emphasis on social aspects such as land tenure, historical injustices, and economic vulnerability of settlers. In some cases, this emphasis might direct the attention away from global demand for cattle and agriculture products as important driver of deforestation and from the attempts to find global solutions. Finally, the framing of sustainability by the Zero Deforestation discourse puts a lot of emphasis on environmental aspects and sustainable supply chains are framed as deforestation and landconversion free. This discourse tends to overlook the lack of agency and vulnerable positions of local farmers.

Legitimacy, for the Zero Deforestation discourse, means to effectively conserve the Amazon. More transparency and traceability are therefore considered as an appropriate tool for deforestation free commodity supply chains. Within cattle supply chains this could be achieved through tracing indirect suppliers (second or third tier calf suppliers) or by making GTAs publicly available. This type of legitimacy is however challenged by the Order and Progress discourse based on an understanding legitimacy as legality - zero legal deforestation is not a requirement by law and third-party actors have no legitimate power to require that from farmers. The political legitimacy of zero gross deforestation is further undermined by claims that it serves the agenda of foreign countries and private funds averse to Brazil developing as an economic power and that it goes against international standards of sovereignty that countries have over their own territories (MacDonald, 2003). Building on this idea, the Livelihoods discourse emphasises consent as an important dimension of legitimacy. It is farmers' right to deforest $20 \%$ of the forest within their private properties (in the
Amazon biome) and consenting to give away that right can only be reached upon agreement and compensation. In contrast, the Zero Deforestation discourse challenges the legitimacy of government regulations, the Forest Code and farmers' legal rights to deforest by pointing to the power of agricultural lobby in legislative branches of the government, to corruption, and to historical land occupation and speculation.

A fairer distribution of benefits and responsibilities is considered the purpose of transparency in all discourses. However, the questions of "which fairness, for whom and why?" is relevant here (Howard et al., 2016). Different dimensions of fairness are emphasised in the different discourses. The Order and Progress discourse considers it unfair that the economic and societal costs of conserving forests are left upon Brazil alone, and that other countries had the chance to exploit their resources for their economic growth. So, it invokes a Rawlsian sense of justice, but only in a narrow sense as to present itself as the least advantaged compared to other nations. The Livelihoods discourse views fairness more from the lens of historical injustices towards settlers and farmers, rather than only a state point-of view. Pushing the cost and responsibility of sustainable and deforestation free cattle upstream to small farmers within this context is unfair. The Zero Deforestation discourse, on the other hand, uses global ethics as a basis for fairness. Deforesting forests that are rich in biodiversity to satisfy increasing consumeristic culture and gain short-term profits is ethically wrong. Inter- and intragenerational injustices are also complementary elements of fairness framed by this discourse. All articulations of fairness therefore draw upon Rawls' second principle of justice that call for the greatest benefit to the least advantaged, but who that least advantaged is differs strongly per discourse: being either Brazil, local farmers, or future generations.

\subsection{The politics of transparency}

The sustainable supply chain is not just an economic or managerial term, but also a political one. As deforestation risk of bovine leather is articulated by different discourses, questions about sustainability, legitimacy, and fairness are answered differently. As a result, we see that 
any choice about how to mitigate deforestation risk of bovine leather depends on the political reality of the actor making that choice. Deforestation risk is mostly invisible in the Order \& Progress discourse so long as cattle is raised and produced within the boundaries set by law and legality. The Livelihoods discourse does acknowledge the strong presence of risk on deforestation but calls upon leather brands and tanneries to take responsibility for mitigating this risk, thus shifting responsibility down the supply chain. The Zero Deforestation discourse points to gaps in legal protection of the Amazon and understands deforestation risk as a more systematic issue, tied to illegal deforestation, political dynamics, and consumerism.

In addition to debating sustainable supply chains, transparency, and deforestation risk as political terms, it is important to highlight the relevance of livelihoods as part of the forest-risk commodity debate. Our results showed the importance of the role and voice of frontier settlers and legal cattle farmers in public debates, by presenting their storylines as part of a discourse on livelihoods. While farmers may be responsible for deforestation, they do make certain reasonable claims to legitimacy and fairness, when they emphasize land ownership and historical injustice. This is especially valid when compared to the discourse coalition that invokes fictional storylines of global conspiracies against the economic development of Brazil. Internationally, public debates on zero deforestation and sustainable supply chains have thus far mostly represented local and international nature conservation organizations, governments and businesses (Taravella and de Sartre, 2012; Pirard et al., 2015; Newton and Benzeev, 2018). While the importance of including local livelihoods in the articulation of international forest policy has been taken up in public debates about policy instruments such as REDD + (Agrawal and Angelsen, 2009; den Besten et al., 2019), such debates are less visible for supply chain governance. Moreover, most programmes that focus on local livelihoods of settlers in Brazil often do so as part of 'low-carbon agriculture' initiatives, instead of directly addressing deforestation risk (Newton et al., 2016).

\section{Conclusions}

For the leather supply chain, we found multiple calls for greater traceability in the beginning (or 'upstream') of the supply chain, i.e. the farmers that rear cattle. Our analysis however showed that this may have negative implications for the fairness of policy interventions and result in ineffective policies that shift the problem to vulnerable actors rather than solve it. The discursive framing of sustainable and transparent supply chains across different discourses moreover has direct impact on how visibility is created (Scott, 1998; Flyverbom, 2016). From the perspective of legitimacy, it also means that transparency mechanisms should report on how consent is given and what justifications are used to stop deforestation, thus moving beyond a mere reporting of legality versus illegality of production. Finally, transparancy mechanisms should give insight in how benefits are distributed and call attention to those who are less advantaged, including local farmers and future generations.

While we argue for more ambition in the supply chain of leather in Brazil, one should also be careful when discounting legal, domestic efforts to curb deforestation as 'not enough'. This can lead to negative political dynamics rather than higher environmental ambition, as is clearly seen today in the current political situation of Brazil. In the past in Brazil, zero deforestation requirements and boycotts in the state of Para (Gibbs et al., 2016) have been experienced as negatively affecting local livelihoods to a great extent. This has resulted in a lack of trust and ownership around zero deforestation commitments by local farmers as they consider themselves "sandwiched" between discourses of government, agricultural lobby, global food markets, and environmental NGOs. Moreover, discounting current efforts could add justification to claims that an environmentalist agenda is being used to slow down Brazil's development by 'kicking away the ladder' (Chang, 2003). Even when a political discourse clearly articulates falsehoods to lay claims to arguments of sustainability, legitimacy, and fairness in order to support a status quo of deforestation, it is still important to take valid arguments from those discourses into account.

Our analysis confirms the idea that a simplistic understanding of transparency or a blind trust in its inherent goodness may lead to negative implications for livelihoods and sustainability outcomes (Klintman and Boström, 2008; Gupta, 2010). Visibility without further engagement and investment causes actors to become economically or politically vulnerable and erodes trust in the system, thus jeopardizing the success of zero deforestation commitments. Even so, our analysis also leads us to believe that transparency is a pre-requisite for sustainability. We argue that the possible success of zero deforestation strategies for the Brazilian leather supply chain will largely depend on the ability to consider the arguments of all three discourses. This means that social criteria of zero deforestation requirements need to go beyond labour standards, land rights and community consultation, and include environmental justice and support for local livelihoods (Newton and Benzeev, 2018). It is now up to international leather markets to find mechanisms for transparent and inclusive supply chains that may bring the ambition of zero deforestation in the Amazon a little closer.

\section{CRediT authorship contribution statement}

Aynur Mammadova: Conceptualization, Methodology, Investigation, Writing - original draft. Jelle Behagel: Conceptualization, Methodology, Resources, Writing - original draft. Mauro Masiero: Conceptualization, Project administration.

\section{Declaration of Competing Interest}

The authors declared that there is no conflict of interest.

\section{Acknowledgement}

We would like to thank the European Forest Institute for their financial support through Short Scientific Visits (SSV) call for Early Stage Researchers. The received fund enabled the research exchange at Wageningen University and Research in 2017. We also appreciate having received travel funds by the Agronomi e Forestali Senza Frontiere ONLUS through "Matteo Cagnoni” Study Scholarship in 2018. The scholarship supported the extensive travel during field work in Brazil in 2018.

\section{References}

Agrawal, A., Angelsen, A., 2009. Using community forest management to achieve REDD + goals. Realising REDD +: National Strategy Pol. Opt. 1, 201-212.

Alix-Garcia, J., Gibbs, H.K., 2017. Forest conservation effects of Brazil's zero deforestation cattle agreements undermined by leakage. Global Environ. Change 47, 201-217.

Armstrong, C., 2016. Fairness, free-riding and rainforest protection. Polit. Theory 44 (1), $106-130$.

Auld, G., Gulbrandsen, L.H., 2010. Transparency in nonstate certification: consequences for accountability and legitimacy. Global Environ. Polit. 10 (3), 97-119.

Azevedo, A.A., Stabile, M.C., Reis, T.N., 2015. Commodity production in Brazil: combining zero deforestation and zero illegality. Elem. Sci. Anth. 3.

Bäckstrand, K., 2008. Accountability of networked climate governance: the rise of transnational climate partnerships. Global Environ. Polit. 8 (3), 74-102.

Barbosa, L.C., 2015. Guardians of the Brazilian Amazon Rainforest: Environmental Organizations and Development. Routledge.

Barreto, P., Pereira, R., Brandão, A., Baima, S., 2017. Will Meat-Packing Plants Help Halt Deforestation in the Amazon? Imazon, Belém, pp. 158.

Beetham, D., 1991. The legitimation of power. Atlantic Highlands. Humanuties Fress International, NJ.

Behagel, J.H., Arts, B.A.S., 2014. Democratic governance and political rationalities in the implementation of the water framework directive in the Netherlands. Public Admin. 92 (2), 291-306.

Behagel, J., Turnhout, E., 2011. Democratic legitimacy in the implementation of the Water Framework Directive in the Netherlands: towards participatory and deliberative norms? J. Environ. Plann. Policy Manage. 13 (3), 297-316.

Bevir, M., 2010. Democratic Governance. Princeton University Press.

Boström, M., Jönsson, A.M., Lockie, S., Mol, A.P., Oosterveer, P., 2015. Sustainable and 
responsible supply chain governance: challenges and opportunities. J. Cleaner Prod. $107,1-7$

Bowman, et al., 2012. Persistence of cattle ranching in the Brazilian Amazon: a spatial analysis of the rationale for beef production. Land Use Policy 29 (3), 558-568.

Chang, H.J., 2003. Kicking away the ladder: Infant industry promotion in historical perspective. Oxford Dev. Stud. 31 (1), 21-32.

Centro das Indústrias de Curtumes do Brasil (CICB) (The Centre for the Brazilian Tanning Industry), 2018. Sobre o couro. Available at: http://www.cicb.org.br/cicb/sobrecouro.

Ciasulli, D. (Ed.), 2019. Fertile ground for investment. Feed \& Food. The Voice of Animal Protein Industry. Available at: http://www.revistafeedfood.com.br/pub/curuca/? numero $=141$ \&edicao $=10989$.

Curtis, P.G., Slay, C.M., Harris, N.L., Tyukavina, A., Hansen, M.C., 2018. Classifying drivers of global forest loss. Science 361 (6407), 1108-1111.

den Besten, J.W., Arts, B., Behagel, J., 2019. Spiders in the web: understanding the evolution of REDD + in Southwest Ghana. Forests 10 (2), 117.

Dingwerth, K., Eichinger, M., 2010. Tamed transparency: how information disclosure under the global reporting initiative fails to empower. Global Environ. Polit. 10 (3), $74-96$.

Egels-Zandén, N., Hansson, N., 2016. Supply chain transparency as a consumer or corporate tool: the case of Nudie Jeans Co. J. Consum. Policy 39 (4), 377-395.

Egels-Zandén, N., Hulthén, K., Wulff, G., 2015. Trade-offs in supply chain transparency: the case of Nudie Jeans Co. J. Clean. Prod. 107, 95-104.

Elgert, L., 2012. Certified discourse? The politics of developing soy certification standards. Geoforum 43 (2), 295-304.

Fearnside, P.M., 2005. Deforestation in Brazilian Amazonia: history, rates, and consequences. Conserv. Biol. 19 (3), 680-688.

Flyverbom, M., 2016. Digital age| transparency: mediation and the management of visibilities. Int. J. Commun. 10, 13.

Food and Agriculture Organization (FAO), 2019. The Brazilian Amazon: Some features of the study area. Accessed March 21, 2019 at: http://www.fao.org/3/j5416e/ J5416E05.htm.

Freitas, F.L., Sparovek, G., Berndes, G., Persson, U.M., Englund, O., Barretto, A., Mörtberg, U., 2018. Potential increase of legal deforestation in Brazilian Amazon after Forest Act revision. Nat. Sustain. 1 (11), 665.

Fung, A., 2013. Infotopia: unleashing the democratic power of transparency. Polit. Soc 41 (2), 183-212.

Fung, A., Graham, M., Weil, D., 2007. Full Disclosure: The Perils and Promise of Transparency. Cambridge University Press.

Gardner, B., 2009. Are livestock a troublesome commodity? Geoforum 40 (5), 781-783.

Gardner, T.A., Benzie, M., Börner, J., Dawkins, E., Fick, S., Garrett, R., et al., 2018. Transparency and sustainability in global commodity supply chains. World Dev.

Garrett, R.D., Carlson, K.M., Rueda, X., Noojipady, P., 2016. Assessing the potential additionality of certification by the round table on responsible soybeans and the roundtable on sustainable palm oil. Environ. Res. Lett. 11 (4), 045003.

Gebara, M., Agrawal, A., 2017. Beyond rewards and punishments in the Brazilian Amazon: practical implications of the REDD + discourse. Forests 8 (3), 66.

Gereffi, G., Humphrey, J., Sturgeon, T., 2005. The governance of global value chains. Rev. Int. Polit. Econ. 12 (1), 78-104.

Gibbs, H.K., Rausch, L., Munger, J., Schelly, I., Morton, D.C., et al., 2015. Brazil's Soy Moratorium. Science 347 (6220), 377-378.

Gibbs, H.K., Munger, J., L'Roe, J., Barreto, P., Pereira, R., Christie, M., et al., 2016. Did ranchers and slaughterhouses respond to zero-deforestation agreements in the Brazilian Amazon? Conserv. Lett. 9 (1), 32-42.

Gibbs, H.K., Ruesch, A.S., Achard, F., Clayton, M.K., Holmgren, P., Ramankutty, N., Foley, J.A., 2010. Tropical forests were the primary sources of new agricultural land in the 1980s and 1990s. Proc. Natl. Acad. Sci. 107 (38), 16732-16737.

Godar, J., Tizado, E.J., Pokorny, B., 2012. Who is responsible for deforestation in the Amazon? A spatially explicit analysis along the Transamazon Highway in Brazil. For. Ecol. Manage. 267, 58-73.

Greenpeace, 2017. Greenpeace Brazil Suspends Negotiations with Cattle Giant JBS. Available at: https://www.greenpeace.org/usa/news/greenpeace-brazil-suspendsnegotiations-cattle-giant-jbs/.

Grunert, K.G., Hieke, S., Wills, J., 2014. Sustainability labels on food products: consumer motivation, understanding and use. Food Policy 44, 177-189.

Grupo de Trabalho da Pecuária Sustentável (GTPS) - Brazilian Roundtable on Sustainable Livestock, 2018. Brazilian Livestock Overview and its Contribution to the Sustainable Development. Available at: https://www.inputbrasil.org/wp-content/uploads/2016/ 10/GTPS_BRAZILIAN-LIVESTOCK-OVERVIEW v3.pdf.

Gupta, A., 2010. Transparency as contested political terrain: who knows what about the global GMO trade and why does it matter? Global Environ. Polit. 10 (3), 32-52.

Gupta, A., Mason, M., 2016. Disclosing or obscuring? The politics of transparency in global climate governance. Curr. Opin. Environ. Sustain. 18, 82-90.

Hajer, M.A., Van Den Brink, M., Metze, T., 2006. Doing discourse analysis: coalitions, practices, meaning. Netherlands Geogr. Stud. (ISSN 0169-4839) 344.

Hajer, M., Versteeg, W., 2005. A decade of discourse analysis of environmental politics: achievements, challenges, perspectives. J. Environ. Plann. Policy Manage. 7 (3), 175-184.

Henders, S., Ostwald, M., 2014. Accounting methods for international land-related leakage and distant deforestation drivers. Ecol. Econ. 99, 21-28.

Henders, S., Persson, U.M., Kastner, T., 2015. Trading forests: land-use change and carbon emissions embodied in production and exports of forest-risk commodities. Environ. Res. Lett. 10 (12), 125012

Higgins, V., Richards, C., 2019. Framing sustainability: alternative standards schemes for sustainable palm oil and South-South trade. J. Rural Stud. 65, 126-134.

Howard, R.J., Tallontire, A.M., Stringer, L.C., Marchant, R.A., 2016. Which "fairness", for whom, and why? An empirical analysis of plural notions of fairness in Fairtrade Carbon Projects, using Q methodology. Environ. Sci. Policy 56, 100-109.

Instituto Brasileiro de Geografia e Estatística (IBGE) (Brazilian Institute of Geography and Statistics), 2018. Sistema IBGE de Recuperação Automática - SIDRA. Pesquisa do Couro e Abate de Animais. Retrieved from: https://sidra.ibge.gov.br/home/abate/ brasil on July 10, 2018.

Instituto Nacional de Pesquisas Espaciais (INPE/Prodes), 2019. Taxas Anuais de Desmatamento. Available at: http://www.obt.inpe.br/OBT/assuntos/programas/ amazonia/prodes (Retrieved on: March 10, 2019).

Janßen, D., Langen, N., 2017. The bunch of sustainability labels-do consumers differentiate? J. Clean. Prod. 143, 1233-1245.

Jakku, E., Taylor, B., Fleming, A., Mason, C., Fielke, S., Sounness, C., Thorburn, P., 2019. "If they don't tell us what they do with it, why would we trust them?" Trust, transparency and benefit-sharing in Smart Farming. NJAS-Wageningen J. Life Sci. 90, 100285.

Kaimowitz, D., Mertens, B., Wunder, S., Pacheco, P., 2004. Hamburger Connection Fuels Amazon Destruction. Center for International Forest Research, Bangor, Indonesia, pp. $1-10$.

Klintman, M., Boström, M., 2008. Transparency through labelling? Layers of visibility in environmental risk management. Transparency in a New Global Order. Unveiling Organizational Visions 178-197.

Koberg, E., Longoni, A., 2018. A systematic review of sustainable supply chain management in global supply chains. J. Clean. Prod.

Larsen, R.K., Dimaano, F.R., Pido, M.D., 2008. Can the Wrongs be Righted? Prospects for Remedy in the Philippine Oil Palm Agro-industry. Development and Change.

Lovejoy, T.E., Nobre, C., 2018. Amazon tipping point. Sci. Adv. 4 (2).

MacDonald, I., 2003. Community-Based Conservation: A Reflection on History.

Mahanty, S., McDermott, C.L., 2013. How does 'Free, Prior and Informed Consent'(FPIC) impact social equity? Lessons from mining and forestry and their implications for REDD + . Land Use Policy 35, 406-416.

Mair, S., Druckman, A., Jackson, T., 2017. Investigating fairness in global supply chains: applying an extension of the living wage to the Western European clothing supply chain. Int. J. Life Cycle Assess. 1-12.

Malterud, K., Siersma, V.D., Guassora, A.D., 2016. Sample size in qualitative interview studies: guided by information power. Qual. Health Res. 26 (13), 1753-1760.

Mason, M., 2008. Transparency for whom? Information disclosure and power in global environmental governance. Global Environ. Polit. 8 (2), 8-13.

Miranda, E., 2018. Tons de verde: a sustentabilidade da agricultura no Brasil (Shades of Green - Sustainable Agriculture in Brazil). Metalivros. ISBN: 8582200196.

Mol, A.P., 2010. The future of transparency: power, pitfalls and promises. Global Environ. Polit. 10 (3), 132-143.

Mol, A.P., 2015. Transparency and value chain sustainability. J. Clean. Prod. 107, $154-161$.

Mol, A., Oosterveer, P., 2015. Certification of markets, markets of certificates: tracing sustainability in global agro-food value chains. Sustainability 7 (9), 12258-12278.

Moutinho, P., Guerra, R., Azevedo-Ramos, C., 2016. Achieving zero deforestation in the Brazilian Amazon: What is missing? Elem. Sci. Anth. 4.

Nepstad, D., McGrath, D., Stickler, C., Alencar, A., Azevedo, A., et al., 2014. Slowing Amazon deforestation through public policy and interventions in beef and soy supply chains. Science 344 (6188), 1118-1123.

Nepstad, D.C., Stickler, C.M., Almeida, O.T., 2006. Globalization of the Amazon soy and beef industries: opportunities for conservation. Conserv. Biol. 20 (6), 1595-1603.

Newberry, D., 2014. Why are there cattle in the conservation area? Social barriers to biofuel governance in Brazil. Geoforum 54, 306-314.

Newton, P., Benzeev, R., 2018. The role of zero-deforestation commitments in protecting and enhancing rural livelihoods. Curr. Opinion Environ. Sustain. 32, 126-133.

Newton, P., Agrawal, A., Wollenberg, L., 2013. Enhancing the sustainability of com modity supply chains in tropical forest and agricultural landscapes. Global Environ. Change 23 (6), 1761-1772.

Newton, P., Gomez, A.E.A., Jung, S., Kelly, T., de Araújo Mendes, T., Rasmussen, L.V., et al., 2016. Overcoming barriers to low carbon agriculture and forest restoration in Brazil: the Rural Sustentável project. World Dev. Perspect. 4, 5-7.

Pacheco, P., 2012. Actor and frontier types in the Brazilian Amazon: assessing interac tions and outcomes associated with frontier expansion. Geoforum 43 (4), 864-874.

Page, E., 2016. Qui bono? Justice in the distribution of the benefits and burdens of avoided deforestation. Res. Publica 22 (1), 83-97.

Parkinson, J., 2003. Legitimacy problems in deliberative democracy. Polit. Stud. 51 (1), 180-196.

Pendrill, F., Persson, M., Godar, J., Kastner, T., 2019. Deforestation displaced: trade in forest-risk commodities and the prospects for a global forest transition. Environ. Res. Lett.

Pereira et al., 2016. Smallholders, Agrarian Reform, and Globalization in the Brazilian Amazon: Cattle versus the Environment. Land 5, 24. doi: 10.3390/land5030024.

Pirard, R., Gnych, S., Pacheco, P., Lawry, S. 2015. Zero-deforestation commitments in Indonesia: Governance challenges. 10.17528/cifor/005871.

Ponte, S., Gibbon, P., 2011. Governing Through Standards: Origins, Drivers and Limitations. Palgrave Macmillan.

Salas-Zapata, W., Ortiz-Munoz, S.M., 2018. Analysis of meanings of the concept of sustainability. Sustain. Dev. 27 (1), 153-161.

Schouten, G., Glasbergen, P., 2011. Creating legitimacy in global private governance: the case of the Roundtable on Sustainable Palm Oil. Ecol. Econ. 70 (11), 1891-1899.

Scott, J.C., 1998. Seeing Like A State: How Certain Schemes to Improve the Human Condition Have Failed. Yale University Press, New Haven, CT, London.

Schneider, C., Coudel, E., Cammelli, F., Sablayrolles, P., 2015. Small-scale farmers' needs to end deforestation: insights for REDD + in São Felix do Xingu (Pará, Brazil). Int. Forest. Rev. 17 (1), 124-142. 
Sharp, L., Richardson, T., 2001. Reflections on Foucauldian discourse analysis in planning and environmental policy research. J. Environ. Plann. Policy Manage. 3, 193-209. Sistema Nacional de Cadastro Ambiental Rural (SICAR), 2019. Prorrogacao. Retrieved May 3. 2019 at: http://www.car.gov.br/\#/saibaMaisProrrogacao.

Taravella, R., de Sartre, X.A., 2012. The symbolic and political appropriation of scales: a critical analysis of the Amazonian ranchers' narrative. Geoforum 43 (3), 645-656.

Torfing, J., 2005. Discourse Theory: Achievements, Arguments, and Challenges. In Discourse theory In European politics. Palgrave Macmillan, London, pp. 1-32.

van der Ven, H., Rothacker, C., Cashore, B., 2018. Do eco-labels prevent deforestation?
Lessons from non-state market driven governance in the soy, palm oil, and cocoa sectors. Global Environ. Change 52, 141-151.

Walker, N., Patel, S., Davies, F., Milledge, S., Hulse, J., Davey, E., 2013. Reducing 'forest footprints': tackling demand for forest-risk commodities. IED Briefing Paper International Institute for Environment and Development. No.17167.

Weber, A.K., Partzsch, L., 2018. Barking up the right tree? NGOs and corporate power for deforestation-free supply chains. Sustainability 10 (11), 3869.

Widerberg, O., Pattberg, P., 2017. Accountability challenges in the transnational regime complex for climate change. Rev. Policy Res. 34 (1), 68-87. 